\title{
Terminal care at home for children with cancer
}

\author{
E J Chambers, A Oakhill, J M Cornish, S Curnick
}

The paediatric oncology unit at this hospital provides an oncology service to the south west of England. Patients from the region come to Bristol for diagnosis and evaluation and to begin treatment. When it is appropriate care is shared between the referring unit and the unit in Bristol.

When a diagnosis is made an information pack is sent to the child's general practitioner giving the diagnosis, describing the unit, and giving details of treatment and probable side effects, thus ensuring a firm link between the specialist unit and the primary care team. ${ }^{1}$ The ensuing period of intense treatment, however, requires close supervision by the hospital, which creates strong links between the families and the specialist unit. We try to keep the general practitioner informed of any important events that occur during treatment. A family support nurse gets to know the family while the child is being treated and as needed visits the child's home to give psychological support, provide family education, and carry out blood tests and physical assessment.

In the event that treatment fails the doctors and the family together decide that anticancer treatment is no longer appropriate, and the emphasis of care changes to relieving physical and mental distress. The aim is to give that child as good a quality of life as possible in the time left to the child. A "home terminal care team" is nominated, consisting of the family support nurse, a social worker, a clinical assistant, and the consultant paediatric oncologist, and we offer that family support for terminal care at home with the general practitioner.

We telephone the general practitioner to say that the decision has been made and to arrange for one of the medical team and the family support nurse to meet the general practitioner and members of the practice within a few days. At this meeting possible medical complications and ways in which these can be actively managed are discussed.

All possible distressing symptoms are considered in the light of the knowledge of the clinical course of the disease and the ways of preventing or treating them considered. A plan of joint care is arranged, tailored to the desired degree of participation of the primary health care team. The hospital facilities remain open to

BrMed f 1989;298:937-40 the child and family at all times and ways of quick and easy communication between the general practitioner and the hospital doctor are planned. Further communication between the two is usually by telephone.

\section{The study}

In the two and a half years from June 1985 to December 1987 there were 35 deaths among the patients referred to one paediatric oncologist. Of these, 19 deaths were in patients who lived in the Avon area and 16 were in those from outside the area. Seven of the 19 patients from Avon died in hospital and 12 died at home. Of those who died in hospital six children were receiving anticancer treatment and one was receiving terminal care. This last child died in hospital, though she had been cared for at home until 24 hours before her death. We report on the 13 patients who received terminal care at home: the 12 who died at home and the one who died in hospital.

Table I gives details of the 13 patients, whose ages ranged from 22 months to 15 years. Seven patients had leukaemia, three had brain tumours, and three had solid tumours. All but one had received chemotherapy and radiotherapy with curative intent. The duration of terminal care was between 10 and 210 days, mean 62 days. The team care provided by the hospital consisted of visits by the doctor, visits by the nurse, and telephone calls from the doctor and nurse. The telephone calls were extremely important, and the number varied from several a day to once a week as required by the medical situation and the need for psychological support. The approximate number of calls per patient ranged from three to 82, mean 37 .

Some general practitioners visited their patients regularly; others did not visit unless called out by the parents (who often called the hospital first in the event of a problem, this being common during anticancer treatment), though the parents knew that the general practitioners were available if needed. General practitioners were closely concerned in most of the cases; eight visited regularly and the remainder were available if called; three visited at the request of the parents and one visited only to certify death. We have arbitrarily divided this into regular visiting or available when needed, designated 1 or 2 respectively in table II. The participation of the district nurse or health visitor was similarly designated 1 or 2 ; these nurses were closely concerned in the care of six of the 13 patients.

\section{Palliation achieved}

Palliation (see table II) was achieved by means of drugs, radiotherapy, chemotherapy, blood products, and home aids. Of primary importance to the well being of the child was that the child was at home surrounded by family and people familiar to the child.

\section{DRUG TREATMENT}

The following classes of drugs were used: analgesics, antiemetics, steroids, anticonvulsants, sedatives, laxatives, antipruritic agents, antibiotics, cardiovascular system drugs, and haemostatic agents.
1 Acute lymphoblastic leukaemia

1 Acute lymphoblastic leukaemia

Neuroblastoma

Ependymoma

6 Acute lymphoblastic leukaemia

$$
\begin{aligned}
& \text { Second relapse } \\
& \text { Third relapse } \\
& \text { Third relapse } \\
& \text { Second relapse } \\
& \text { First relapse }
\end{aligned}
$$$$
\begin{aligned}
& \text { First relapse } \\
& \text { Second relapse }
\end{aligned}
$$

Home

Hospita

Home

Hom 


\begin{tabular}{|c|c|c|c|c|c|c|c|c|c|}
\hline $\begin{array}{l}\text { Case } \\
\text { No }\end{array}$ & Diagnosis & Mode of death & $\begin{array}{l}\text { No of } \\
\text { medical } \\
\text { visits }\end{array}$ & $\begin{array}{l}\text { No of visits } \\
\text { by family } \\
\text { support } \\
\text { nurse }\end{array}$ & $\begin{array}{c}\text { General } \\
\text { prac- } \\
\text { titioner } \\
\text { care }^{\star}\end{array}$ & $\begin{array}{l}\text { Community } \\
\text { nurse care }\end{array}$ & Drugs used & $\begin{array}{l}\text { Chemotherapy } \\
\text { or radiotherapy }\end{array}$ & $\begin{array}{l}\text { Blood } \\
\text { products }\end{array}$ \\
\hline 1 & $\begin{array}{l}\text { Acute } \\
\text { myelomonocytic } \\
\text { leukaemia }\end{array}$ & Coma & 2 & 6 & 1 & 1 & $\begin{array}{l}\text { Diamorphine, } \\
\text { laxatives, } \\
\text { prochlorperazine, } \\
\text { trimeprazine }\end{array}$ & $\begin{array}{l}\text { Intrathecal } \\
\text { chemotherapy }\end{array}$ & No \\
\hline 2 & $\begin{array}{l}\text { Juvenile chronic } \\
\text { myeloid leukaemia }\end{array}$ & $\begin{array}{l}\text { Coma; } \\
\text { pneumonia }\end{array}$ & 4 & 1 & 2 & 1 & $\begin{array}{l}\text { Diamorphine, } \\
\text { paracetamol }\end{array}$ & None & No \\
\hline 3 & Retinoblastoma & $\begin{array}{l}\text { Fitting; } \\
\text { haematemesis }\end{array}$ & 4 & 6 & 1 & 1 & $\begin{array}{l}\text { Diamorphine, } \\
\text { prochlorperazine, } \\
\text { diazepam }\end{array}$ & None & No \\
\hline 4 & Glioma & Coma & 1 & 2 & 2 & $?$ & $\begin{array}{l}\text { Dexamethasone, } \\
\text { laxatives }\end{array}$ & None & No \\
\hline 5 & Astrocytoma & Fitting; coma & 6 & 32 & 1 & 1 & $\begin{array}{l}\text { Carbamazepine, } \\
\text { prochlorperazine, } \\
\text { diazepam, } \\
\text { diamorphine }\end{array}$ & Radiotherapy & No \\
\hline 6 & Rhabdomyosarcoma & Coma & 3 & 32 & 1 & 1 & $\begin{array}{l}\text { Diamorphine, } \\
\text { prochlorperazine, } \\
\text { laxatives }\end{array}$ & Radiotherapy & No \\
\hline 7 & $\begin{array}{l}\text { Acute myeloid } \\
\text { leukaemia }\end{array}$ & Sudden coma & 7 & 8 & 2 & 2 & $\begin{array}{l}\text { Paracetamol, digoxin, } \\
\text { diuretics, } \\
\text { antibiotics } \\
\text { (intravenous) }\end{array}$ & Radiotherapy & $\begin{array}{l}\text { Platelets } \times 1 \text {; } \\
\text { blood }\end{array}$ \\
\hline 8 & $\begin{array}{l}\text { Acute lymphoblastic } \\
\text { leukaemia }\end{array}$ & Coma & 8 & 19 & 1 & 1 & $\begin{array}{l}\text { Morphine sulphate, } \\
\text { diamorphine, } \\
\text { topical thrombin, } \\
\text { laxatives }\end{array}$ & None & $\begin{array}{l}\text { Platelets } \times 1 \text {; } \\
\text { blood }\end{array}$ \\
\hline 9 & $\begin{array}{l}\text { Acute lymphoblastic } \\
\text { leukaemia }\end{array}$ & Coma & 15 & 9 & 1 & 2 & $\begin{array}{l}\text { Diamorphine, } \\
\text { chlorpromazine, } \\
\text { diazepam, } \\
\text { laxatives, } \\
\text { tranexamic acid }\end{array}$ & None & No \\
\hline 10 & $\begin{array}{l}\text { Acute lymphoblastic } \\
\text { leukaemia }\end{array}$ & Coma & 20 & 13 & 1 & 2 & $\begin{array}{l}\text { Morphine sulphate } \\
\text { tablets, } \\
\text { diamorphine, } \\
\text { laxatives }\end{array}$ & None & No \\
\hline 11 & Neuroblastoma & Coma & 4 & 2 & 2 & 2 & $\begin{array}{l}\text { Diamorphine, } \\
\text { paracetamol, } \\
\text { tranexamic acid, } \\
\text { topical thrombin }\end{array}$ & Radiotherapy & $\begin{array}{l}\text { Blood } \times 2 ; \\
\text { platelets } \times 2\end{array}$ \\
\hline 12 & Ependymoma & Coma & 1 & 12 & 1 & 2 & $\begin{array}{l}\text { Diamorphine, } \\
\text { dexamethasone, } \\
\text { prochlorperazine/ } \\
\text { promethazine, } \\
\text { atropine, laxatives }\end{array}$ & None & No \\
\hline 13 & $\begin{array}{l}\text { Acute lymphoblastic } \\
\text { leukaemia }\end{array}$ & Sudden coma & 1 & 8 & 2 & 2 & $\begin{array}{l}\text { Diamorphine, } \\
\text { paracetamol, } \\
\text { promethazine }\end{array}$ & Radiotherapy & $\begin{array}{l}\text { Blood; } \\
\text { platelets } \times 1\end{array}$ \\
\hline
\end{tabular}

${ }^{\star} 1=$ regular visiting; $2=$ available when needed.

\section{Analgesics}

Diamorphine was chosen as the strong analgesic. Nine patients received regular doses and three received occasional doses. For the nine patients receiving regular treatment, diamorphine was initially given orally (in one case through a nasogastric tube) to seven and through a central venous catheter initially to two (table III). In three patients it was necessary to convert

\begin{tabular}{|c|c|c|c|c|}
\hline $\begin{array}{c}\text { Case } \\
\text { No }\end{array}$ & $\begin{array}{l}\text { Central } \\
\text { venous } \\
\text { catheter }\end{array}$ & $\begin{array}{l}\text { Regular } \\
\text { diamorphine } \\
\text { treatment }\end{array}$ & Initial route & $\begin{array}{l}\text { Control } \\
\text { of pain }\end{array}$ \\
\hline 1 & Yes & Yes & Intravenous & Smooth \\
\hline 2 & No & No & Oral & Pain free \\
\hline 3 & Yes & Yes & Intravenous & Difficult \\
\hline 4 & No & No & - & Pain free \\
\hline 5 & No & No & Oral & Pain free \\
\hline 6 & Yes & Yes & Oral $\rightarrow$ intravenous & Smooth \\
\hline 7 & Yes & No & - & Pain free \\
\hline 8 & No & Yes & Oral $\rightarrow$ rectal & Smooth \\
\hline 9 & No & Yes & $\begin{array}{l}\text { Oral } \rightarrow \text { peripheral } \\
\text { intravenous }\end{array}$ & Difficult \\
\hline 10 & Yes & Yes & Oral $\rightarrow$ intravenous & Difficult \\
\hline 11 & Yes & Yes & Oral & Smooth \\
\hline 12 & No & Yes & Nasogastric tube & Smooth \\
\hline 13 & Yes & Yes & Oral & Smooth \\
\hline
\end{tabular}

$\rightarrow=$ converted to.

trom oral administration in the last few days of life. One (case 6) already had a central venous catheter in situ; one (case 9) received diamorphine through a peripheral intravenous infusion pump; and treatment in case 8 was changed from oral to rectal administration just before death. Pain control was considered to be adequate in six of the nine patients with regular diamorphine treatment and less than adequate at times in cases 3,9 , and 10 .

One of these patients (case 3) received diamorphine through a central venous catheter and required rapidly escalating doses of diamorphine-a 14-fold increase in the first eight days. On the day she died it was necessary to increase the dose a further threefold to control the pain. Pain in the second patient (case 9) was controlled initially with slow release morphine and occasional doses of diamorphine in between. Four days before his death severe limb pain led to loss of pain control with oral slow release morphine sulphate and he was started on an intravenous infusion pump, which gave good pain relief over the final three days. The doses required in his final days were some 15 times higher than those given orally allowing for different bioavailability. The third patient (case 10) required large doses of diamorphine intravenously in his last few hours when his pain escalated suddenly. We learnt not to hesitate to increase the dose of diamorphine, occasionally giving doses over $1 \mathrm{~g}$ four hourly to achieve control of pain.

\section{Antiemetics}

Six patients were taking antiemetics regularly. Of these, four had raised intracranial pressure and the use of antiemetics preceded or coincided with the use of diamorphine. Only two patients required antiemetics for nausea and vomiting possibly induced by diamorphine; this was easily controlled in both. The drug chosen was prochlorperazine, which was given either intravenously or rectally. Chlorpromazine and promethazine were also used. Reasonable control of 
vomiting was achieved in all patients except one (case 3), who had widespread disease of the central nervous system from a retinoblastoma.

\section{Steroids}

Two patients were taking dexamethasone for raised intracranial pressure at some time during their terminal illness. In case 4 this was tailed off before death, but in case 12 treatment continued until death.

\section{Anticonvulsants}

Two patients required anticonvulsant drugs. One took carbamazepine regularly for temporal lobe attacks and the other (case 3) had a seizure as a terminal event. Parents of patients in whom there was a high chance of seizures occurring were given diazepam to administer rectally or intravenously and instructed in its use.

\section{Laxatives}

All patients taking diamorphine were given laxatıves. Enemas were required by one patient (case 3), who had spinal cord compression from tumour that complicated her management, and two patients required occasional enemas.

\section{Miscellaneous}

One patient took trimeprazine for sedation at night and one oral diazepam for anxiety. We did not prescribe sedatives for other patients, though sedation occurred as a side effect of analgesic or antiemetic drugs, or both. A patient who was in incipient cardiac failure from cardiomyopathy induced by anthracyclines (case 7) was treated with digoxin and frusemide; he was the only patient to receive intravenous antibiotics at home as terminal care was started while he was being treated for a neutropenic fever. His quality of life was excellent at the time and so it was decided not to precipitate a possible septicaemia.

\section{RADIOTHERAPY}

Five of the 13 patients received palliative radiotherapy to six sites. Two patients were treated for enlarging, painful lymph nodes in the neck, caused by acute myeloid leukaemia in one and by metastatic neuroblastoma in one. In both patients lymph node shrinkage was achieved with three doses of $500 \mathrm{cGy}$ over six days with minimal upset. The first (case 5), who had a thalamic astrocytoma, received $2500 \mathrm{cGy}$ in 10 fractions to the brain stem at time of relapse; there was slight improvement initially, though it is impossible to judge how this influenced her final illness. The second (case 6), who had metastatic rhabdomyosarcoma, had palliative radiotherapy to the very large primary tumour in his calf, which was threatening to fungate before his death from chest metastases. He received $3500 \mathrm{cGy}$ in five fractions over 14 days; he died 63 days later with the skin over his calf intact. Two patients received radiotherapy to limbs for bone pain. One patient (case 11), who had metastatic neuroblastoma, received a single $500 \mathrm{cGy}$ fraction to the thigh, after which she was able to ride her bicycle without needing more analgesics. The other (case 13), who had acute lymphoblastic leukaemia, also received a single $500 \mathrm{cGy}$ fraction to both thighs; her analgesic requirement remained stable for 13 days. Excellent liaison between the paediatric oncology department and the radiotherapy centre meant that it was possible to arrange radiotherapy immediately.

\section{CHEMOTHERAPY}

One patient (case 1) received intrathecal chemotherapy for palliation of symptoms of raised intracranial pressure. It produced an improvement in symptoms and was repeated once when headache and vomiting recurred. The aim of intrathecal chemotherapy in this boy was to control his central nervous system disease, which would produce a painful and unpleasant death. Death from bone marrow failure usually is less distressing.

\section{BLOOD PRODUCTS}

Only four patients received blood products. They each received both packed red cells and platelets. Three received transfusions of packed cells early in their terminal illness when the quality of life was enhanced by a rise in haemoglobin. The fourth (case 11) received three infusions of packed cells in the 37 days of her terminal illness; she was active at home for 35 of those days.

Despite seven patients having leukaemia and one having bone marrow failure from neuroblastoma, bleeding as a result of thrombocytopenia was not a great problem. Two of the above patients received one transfusion of platelets each and one patient two transfusions of platelets. Tranexamic acid and topical thrombin were given to one patient for bleeding from gums (this was not successful) and tranexamic acid alone to one patient, in whom it controlled epistaxis without platelet transfusion.

\section{HOME AIDS}

A variety of home aids were provided (table IV).

TABLE IV—Home aids provided

\begin{tabular}{|c|c|c|}
\hline Case No & Source & Aids provided \\
\hline 1 & Hospital & Spenco mattress, sheepskin, mouthcare packs \\
\hline 2 & - & Not needed \\
\hline 3 & Hospital & Sheepskin, catheter equipment, mouthcare packs \\
\hline 4 & Hospital & Buggy, incontinence pads \\
\hline 5 & $\begin{array}{l}\text { Community } \\
\text { Hospital }\end{array}$ & $\begin{array}{l}\text { Ripple mattress, incontinence aids, mouthcare packs } \\
\text { Sheepskin }\end{array}$ \\
\hline 6 & Community & $\begin{array}{l}\text { Ripple mattress, incontinence aids, mouthcare packs, } \\
\text { commode }\end{array}$ \\
\hline & Hospital & Sheepskin, urinals \\
\hline 7 & Hospital & Spenco mattress, mouthcare packs \\
\hline 8 & $\begin{array}{l}\text { Hospital } \\
\text { Community }\end{array}$ & $\begin{array}{l}\text { Sheepskin, urinals, mouthcare packs, buggy } \\
\text { Incontinence aids }\end{array}$ \\
\hline 9 & Hospital & $\begin{array}{l}\text { Buggy, Spenco mattress, sheepskin, mouthcare pack, } \\
\text { incontinence aids }\end{array}$ \\
\hline 10 & Hospital & $\begin{array}{l}\text { Ripple mattress, sheepskin, mouthcare packs, syringe } \\
\text { driver, urinal }\end{array}$ \\
\hline 11 & Hospital & Mouthcare packs \\
\hline 12 & Hospital & $\begin{array}{l}\text { Buggy, sheepskin, mouthcare packs, incontinence } \\
\text { aids, nasogastric tube, suction machine, intercom }\end{array}$ \\
\hline 13 & Hospital & Sheepskin, buggy, mouthcare packs \\
\hline
\end{tabular}

Mouthcare packs were required for 11 patients, sheepskins for nine, incontinence aids for six, and buggies for five. Ripple mattresses were provided for three and Spenco mattresses for three. One each of the following was also provided: syringe driver, nasogastric suction apparatus, and an intercom. The hospital was largely responsible for the aids for 10 patients and the community for aids for two patients.

The family support nurse was responsible for a large part of the terminal care. She visited patients often, the number of visits ranging from 1-32, mean 12 . She also telephoned the families. She gave counselling and support, practical advice, and advice about drugs. She also saw that the families got many of the aids required at home to make the child more comfortable and help the parents to care for the child.

\section{Mode of death}

Eleven of the 13 patients died in a coma; this was gradual in seven and sudden in three, and one patient developed pneumonia and died peacefully 24 hours later. In two patients death was traumatic, one associated with seizures and haematemesis, the other preceded by a sudden onset of severe pain and the need for an increase in the dose of diamorphine. One 
further patient (case 5) had seizures on the day of death, despite the family having diazepam for rectal administration.

\section{Bereavement}

Bereavement care was largely carried out by the family support nurse, though all families were visited at home by a member of the medical team after the child's death and one or two members of the terminal care team attended each funeral. A mean of eight bereavement vitist were made to each family in the first year after death. Parents were encouraged to visit the hospital if they felt able, and all were offered a consultation with the consultant paediatric oncologist after the child's death at a venue outside the hospital if they preferred.

\section{Discussion}

Many parents wish to care for their dying child at home. By working closely with general practitioners and educating and supporting parents we can achieve this. The parents gain confidence through knowing that the hospital team (on whom they may have become dependent) wishes to continue caring for their child at home with the general practitioner and that the hospital facilities are available to them if required. Knowing the likely course of a particular disease allows the care team to anticipate distressing symptoms and be able to deal with them effectively with the parents.

Potential symptoms in the 13 children that were preempted or treated promptly included pain, constipation, vomiting, seizures, and bleeding. The likely site of pain, its cause, and how it could be relieved was discussed with the child's parents so that they knew, for example, that a child with leukaemia was likely to develop limb pain from bone marrow infiltration and that this could be readily relieved with radiotherapy. All parents were well informed about the use of diamorphine, how to titrate the dose against pain, and the likely side effects - for example, that drowsiness would probably improve after $24-48$ hours, but constipation was guaranteed if laxatives were not given. They therefore felt confident that they could keep their child free of pain. If the child was taking non-opiate analgesics they knew opiates were available when needed or, if appropriate, were supplied with opiates and instructions for their use.

There was a large variation in the dose of opiates needed. Most patients were taking oral analgesics, but the presence of a central venous catheter was helpful in three patients in whom oral treatment was not possible during their terminal illness. This is of particular value in very young children or children who fear needles. We now consider placing central venous catheters in patients in whom pain and bleeding are likely to be major problems in terminal care.

Most parents were familiar with the use of antiemetics because of previous chemotherapy. All, however, were warned that if nausea or vomiting occurred antiemetics could be given by a suitable route. When seizures were a possibility diazepam for rectal administration was kept in the home for emergency use.

Bleeding is very distressing to both child and parent. Multiple transfusions of platelets were not necessary for our patients, though three patients received one transfusion each and one patient two transfusions for bleeding. Platelets were given only when signs of bleeding occurred (and were not given prophylactically).

Bleeding from the gums can sometimes be managed with tranexamic acid if there is no haematuria and so no risks of clotting in the renal tract. Scrupulous attention to oral hygiene is important in prevention here.
Topical thrombin was used once in one patient without success, but it is sometimes successful. It is now available only on a named patient basis.

In three patients there was loss of pain control. In two this occurred on their final day and their deaths were not peaceful. In one of these seizures occurred, too, contributing to a traumatic death. We are now prepared to use very large doses of diamorphine and to be more specific with our instructions concerning the use of anticonvulsant drugs. Despite our aims of keeping the children free of distressing symptoms and preparing for a peaceful death, we failed to achieve this in three patients.

The likely mode of death of each child was discussed with their parents. This is something that causes considerable anxiety, and Kohler and Radford ${ }^{2}$ found that over half the parents in their study expressed anxiety about what would happen at the moment of death. Most of the children in our study and theirs died peacefully. It is therefore possible to offer reassurance on this point and be correct in most cases.

Expecting and preventing symptoms, the liaison between the hospital and the primary health care team, and the work of the family support nurse who helped that liaison were all important. Once a decision for terminal care at home had been taken the child no longer attended the oncology unit routinely, and medical and nursing assessment was carried out in the home. Parents, however, had access to hospital medical staff for advice by telephone at all times. Drug control remained in the hands of the hospital team in most cases.

Most children who are terminally ill can be supported at home, should this be the wish of the child and parent.

We thank the Cancer and Leukaemia in Childhood Trust for funding the domiciliary care nurse. 1 James JA, Harris DJ, Mott MG, Oakhill A. Paediatric oncology information
pack for general practitioners. Br Med $\mathcal{F}$ 1988;296:97-8.

2 Kohler JA, Radford M. Terminal care for children dying of cancer: quantity and quality of life. $\mathrm{Br} \mathrm{Med} \mathcal{J}$ 1985;291:115-6.

(Accepted 31 fanuary 1989)

\section{ANY QUESTIONS}

Is dementia caused by neurosyphilis reversible with treatment?

Over $90 \%$ of patients with neurosyphilis who are treated with adequate doses of penicillin are "cured." The demonstration of cure necessitates repeated examinations of the cerebrospinal fluid over two years. If neurosyphilis is diagnosed in its early stages most patients show considerable clinical improvement and in some instances total reversal of symptoms and signs, including early dementia. If the patient presents late, or diagnosis and treatment are delayed, there may be no improvement in the clinical picture. It is essential that the initial treatment is adequate and that the cerebrospinal fluid is re-examined at intervals for two years, as relapses may occur after insufficient early treatment. Relapses are unlikely if the pleocytosis and raised concentration of protein in the cerebrospinal fluid return to normal-usually within four to 12 months. The results of the Venereal Disease Research Laboratory and fluorescent treponomal antibody tests may remain positive.

For those patients allergic to penicillin, tetracycline or erythromycin for 30 days are adequate alternatives, though the failure rate tends to be higher and careful monitoring in such patients is essential. - J M S PEARCE, consultant neurologist, Hull 